\title{
Analisis Penggunaan Multimedia Pembelajaran Interaktif terhadap Motivasi Belajar Peserta Didik pada Mata Pelajaran Matematika
}

\author{
Saepuloh $^{1 \bowtie}$ dan Khomsatun Ni’mah ${ }^{2}$ \\ ${ }^{1,2}$ Program Studi Magister Pendidikan Matematika, Pascasarjana, Universitas Siliwangi
}

\begin{tabular}{l}
\hline Info Artikel \\
\hline Sejarah Artikel: \\
Diterima 4 Feb 2021 \\
Direvisi 28 Mar 2021 \\
Disetujui 17 Apr 2021 \\
\hline Keywords: Computer- \\
Based Interactive \\
Multimedia, Lectora \\
Inspire, Students \\
Motivation in learning \\
Math \\
\hline Papertype: \\
Research paper \\
\hline
\end{tabular}

\begin{abstract}
The purpose of this study was to determine and identify the extent how far the use of computer-based interactive multimedia made by the Lectora application on the motivation of students and their responses. The author uses qualitative research method with a descriptive approach. The research was held at MA Assa'adah Jamanis Tasikmalaya. The research subjects were students and mathematics teachers $10^{\text {th }}$ grade. The selection was made purposively. Because of the Covid 19 pandemic condition, the number of students is limited to 50\% of the computer laboratory capacity, which is 16 people. The technique of collection data are semi-structured interviews, observation of active participation in data collection, and documentation. The instruments used in this study are (1) interview instruments, (2) observation instruments, (3) document instruments. Data were analyzed using the Analysis Interactive model with several stages, namely data collection, data reduction, data presentation, and drawing conclusions. The results showed that the use of interactive multimedia learning media, students were motivated and active. They feel happy and challenged. They also don't feel bored when they are at the computer. This learning media presents material complete and attractive material. This interactive learning media is easy to use, contains mathematical concepts, material can be repeated, both written and video material. This media can create a more focused learning condition. The media is relevant to the material being studied. However, it is important to note, that although technology can be learning resource, it still cannot replace the teacher's position.
\end{abstract}

\begin{abstract}
Abstrak
Tujuan penelitian ini adalah untuk mengetahui dan mengidentifikasi sejauh mana dampak penggunaan multimedia interaktif berbasis komputer yang dihasilkan dengan aplikasi lectora terhadap motivasi peserta didik beserta tanggapan-tanggapannya. Penulis menggunakan metode penelitian kualitatif dengan memakai pendekatan deskriptif. Penelitian dilakukan di MA Assa'adah Jamanis Tasikmalaya. Subjek penelitiannya adalah peserta didik dan guru Matematika kelas X. Pemilihannya dilakukan secara purposive. Karena dalam kondisi pandemi covid 19, jumlah peserta didik dibatasi sebanyak 50\% dari kapasitas laboratorium komputer yaitu 16 orang. Teknik pengumpulan data penelitian ini dengan cara wawancara semi terstruktur, observasi partisipasi aktif dalam pengumpulan data, dan dokumentasi. Instrumen yang digunakan yaitu (1) Instrumen wawancara, (2) Instrumen observasi, (3) Instrumen dokumen. Data dianalisis menggunakan model Analysis Interactive dengan beberapa tahapan yaitu pengumpulan data, reduksi data, penyajian data, dan penarikan kesimpulan. Hasil penelitian menunjukkan bahwa dengan penggunaan media pembelajaran multimedia interaktif, peserta didik menjadi termotivasi dan aktif. Mereka merasa senang dan tertantang. Mereka juga tidak merasa bosan ketika berada di depan komputer. Media pembelajaran ini menyajikan materi dengan lengkap dan menarik. Media pembelajaran interaktif ini mudah digunakan, memuat konsep-konsep dan pemahaman matematika, bisa mengulang materi, baik materi tertulis maupun video. Media ini bisa menciptakan kondisi pembelajaran yang lebih terarah. Media yang digunakan relevan dengan materi yang sedang di pelajari. Namun, penting untuk diperhatikan, bahwa walaupun teknologi bisa menjadi sebagai sumber belajar, tapi tidak bisa menggantikan posisi guru.
\end{abstract}

(C) 2021 Universitas Muria Kudus 
Saepuloh dan Khomsatun Nimah

Anargya: Jurnal Pendidikan Matematika, Vol. 4 No.1, April 2021

https://dx.doi.org/10.24176/anargya.v4i1.5860

Program Studi Pendidikan Matematika

e-ISSN 2615-4072

Fakultas Keguruan dan Ilmu Pendidikan Universitas Muria Kudus

Kampus UMK Gondangmanis, Bae Kudus Gd. L. It I PO. BOX 53 Kudus

Tlp (0291) 438229 ex.147 Fax. (0291) 437198

E-mail: fadarmm@gmail.com 


\section{PENDAHULUAN}

Pembelajaran pada dasarnya adalah sebagai suatu usaha yang dilakukan oleh guru atau pengajar secara sadar untuk membantu peserta didik supaya bisa belajar sesuai dengan minat dan kebutuhan masing-masing. Hal ini dilakukan untuk memanipulasi sumber belajar supaya proses belajar yang dilakukan peserta didik bisa terlaksana, yang mana peserta didik sebagai sumber yang belajar dan guru sebagai subjek yang mengajar (Kustandi, 2020).

Pada saat ini, ilmu pengetahuan dan teknologi terus berkembang dengan sangat pesatnya. Pada masa sekarang ini sudah seharusnya ilmu pengetahuan dan teknologi bisa menjangkau ke seluruh lapisan masyarakat dalam sektor pendidikan. Penggunaan komputer di dalam pembelajaran sebagai media pembelajaran sudah seharusnya digunakan. Pembelajaran berbasis komputer merupakan pembelajaran yang menerapkan penggunaan komputer dalam proses belajar mengajar, baik digunakan oleh peserta didik maupun guru (Kustandi, 2019).

Hal ini dilakukan untuk pencapaian hasil pembelajaran yang optimal. Salah satu penggunaan komputer dalam pembelajaran adalah dalam model multimedia pembelajaran interaktif. Multimedia yang dimaksud adalah media presentasi dengan menggabungkan teks, audio dan visual (Karsidi, 2019). Penggunaan multimedia menjadi suatu alternatif yang sesuai dengan tujuan pelaksanaan pembelajaran yang berkesan. Pada era globalisasi seperti saat ini, multimedia sangat diperlukan dalam proses pembelajaran, karena multimedia melibatkan beberapa unsur indra (Wahyuni, E. S., \& Yokhebed, Y., 2019).

Dalam proses belajar mengajar, seorang guru hendaknya memperhatikan permasalahan dari segi psikis atau afektif disamping aspek kognitif. Ada peserta didik yang memiliki masalah dari segi psikis atau afektif. Salah satu aspek dari hal terebut adalah motivasi belajar. Motivasi belajar merupakan salah satu faktor psikis yang sifatnya non-intelektual dan menunjang keberhasilan proses pembelajaran termasuk di dalamnya pembelajaran matematika (Sardiman, 2012).

Kurangnya motivasi peserta didik ini juga mempengaruhi keaktifan peserta didik dalam proses belajar mengajar, sehingga peserta didik kurang semangat dalam belajar matematika, apalagi menuju siang hari. Seseorang yang belajar dengan memiliki motivasi yang tinggi akan melaksanakan kegiatan pembelajarannya dengan sungguh-sungguh dan penuh semangat. Sebaliknya peserta didik yang belajar dengan memiliki motivasi yang rendah akan malas bahkan tidak mau mengerjakan tugas-tugas yang berhubungan dengan mata pelajaran matematika. Faktor psikologis peserta didik bisa dilihat dari adanya motivasi belajar, rasa ingin tahu, dan kepercayaan diri peserta didik (Wijayanti, 2019).

Karena dengan berhasilnya peserta didik memiliki motivasi untuk belajar, bisa menumbuhkembangkan kemampuan mereka dan meningkatkan prestasi. Untuk membangkitkan motivasi belajar peserta didik, maka diperlukan dukungan dari guru. Motivasi ini bertujuan untuk membentuk pembelajaran yang berkesan, sehingga menambah semangat belajar pada peserta didik, karena ada hubungan yang erat antara motivasi dan semangat belajar. Pemanfaatan media pembelajaran berupa multimedia interaktif dalam pembelajaran atau proses belajar mengajar menjadi salah satu cara yang bisa dilakukan untuk menumbuhkan motivasi belajar peserta didik dalam belajar. Kegiatan pembelajaran yang bermakna menjadi satu faktor yang mempunyai pengaruh besar dalam upaya tercapainya tujuan pendidikan. Penggunaan media pembelajaran yang tepat, bisa menjadikan waktu yang efektif dan juga efisien (Suryani, 2019).

Permasalahan yang ditemukan di MA Assa'adah adalah bahwa umumnya guru masih menggunakan metode ceramah dalam proses pembelajaran matematika. Guru jarang dan bahkan tidak terbiasa menggunakan media pembelajaran khususnya yang berbasis IT dan belum mahir dalam membuat media pembelajaran interaktif. Ini dikarenakan belum ada sosialisasi tentang peningkatan keterampilan dan kreativitas guru melalui pengembangan media pembelajaran interaktif. Seharusnya, guru dituntut untuk dapat mengembangkan keterampilan membuat media pembelajaran, apalagi media tersebut belum tersedia di sekolah/ madrasah.

Sehingga perlu adanya media pembelajaran interaktif yang perlu dikembangkan bagi para guru untuk dapat menggunakan media pembelajaran berbasis multimedia ini. Maka penulis mengembangkan media pembelajaran yang inovatif dan lebih menarik, yaitu dengan membuat media pembelajaran interaktif. Multimedia pembela-jaran yang digunakan pada penelitian ini ialah multimedia interaktif yang dihasilkan oleh aplikasi Lectora. 
Lectora Inspire adalah sebuah aplikasi komputer yang merupakan alat pengembangan belajar berbasis komputer. Lectora ini dikembangkan oleh Perusahaan Trivantis Corporation. Lectora Inspire yang dapat digunakan untuk membuat presentasi maupun multimedia pembelajaran interaktif, karena bisa digunakan untuk menyampaikan konten digital dengan kombinasikombinasi antara audio, teks, gambar, video dan animasi secara keseluruhan yang terpadu, (Wulandari, dkk).

Lectora Inspire merupakan aplikasi yang efektif dalam membuat media pembelajaran. Lectora Inspire relatif mudah diaplikasikan atau diterapkan karena tidak memerlukan pemahaman bahasa pemrograman atau coding yang canggih. Lectora Inspire memiliki antarmuka yang tidak asing lagi dengan kita. Dengan menggunakan Lectora Inspire, materi pelajaran yang disusun akan lebih menarik dengan menampilkan video, serta gambar-gambar animasi yang berhubungan dengan materi pelajaran. Tentunya ini akan menumbuhkan motivasi peserta didik, sehingga mereka lebih memperhatikan apa yang disampaikan oleh guru. Proses pembelajaran akan lebih menyenangkan dan bermakna, sehingga berpengaruh pada peningkatan prestasi belajar peserta didik.

Di dalam penelitian ini penulis akan menganalisis penggunaan media pembelajaran multimedia interaktif berbasis komputer yang dihasilkan oleh Lectora Inspire dalam proses kegiatan pembelajaran di MA Assa'adah. Tujuannya untuk mengetahui dan mengidentifikasi sejauh mana dampak penggunaan multimedia interaktif berbasis komputer dengan aplikasi Lectora ini terhadap motivasi peserta didik beserta tanggapantanggapannya.

\section{METODE PENELITIAN}

Pada penelitian ini penulis menggunakan metode penelitian kualitatif dengan memakai pendekatan deskriptif. Pendekatan ini didasarkan pada pendeskripsian perilaku subjek yaitu guru matematika dan peserta didik sesuai dengan situasi yang ada. Metode penelitian kualitatif sering disebut dengan metode penelitian naturalistis karena penelitiannya dilakukan pada kondisi yang alamiah atau natural setting (Sugiyono, 2019).

Penelitian ini dilakukan di MA Assa'adah Kec. Jamanis Kab. Tasikmalaya. Subjek dalam penelitian ini adalah peserta didik kelas $\mathrm{X}$ dan guru matematika kelas $\mathrm{X}$. Pemilihan subjek penelitian dalam penelitian ini dilakukan dengan cara sengaja (purposeful), tidak secara acak untuk mengumpulkan data yang diinginkan (Wijayanti, 2019). Karena dalam kondisi pandemi covid-19, jumlah peserta didik yang diambil dibatasi sebanyak 50\% dari kapasitas laboratorium komputer yaitu 16 orang, tentunya dengan protokol kesehatan yang ketat.

Sebagai informasi data penelitian, penulis mengambil sumber informasi data yaitu guru matematika dan peserta didik yang menggunakan media interaktif ini. Subjek penelitian tersebut sengaja dipilih dalam penelitian kualitatif ini karena dianggap dapat memberikan informasiinformasi yang terpercaya mengenai elemenelemen yang ada.

Untuk pengambilan data, peneliti melakukan observasi secara langsung pada saat pembelajaran matematika di laboratorium komputer. Teknik pengumpulan data penelitian ini dengan cara wawancara semi terstruktur, observasi partisipasi aktif dalam pengumpulan data, dan dokumentasi.

Instrumen yang digunakan dalam penelitian ini adalah: (1) Instrumen wawancara, yang mana dalam penelitian ini dilakukan bukan hanya bertujuan untuk mengajukan pertanyaan saja, melainkan juga untuk mendapatkan pengalaman secara langsung dari narasumber, yaitu dari guru dan peserta didik yang menggunakan multimedia interaktif berbasis komputer ini. (2) Instrumen observasi, yang berfungsi sebagai panduan untuk melihat objek penelitian secara langsung, sehingga mampu mencatat dan menghimpun data-data yang diperlukan dalam penelitian guna mengungkap penelitian yang sedang dilakukan. Observasi pada penelitian ini hanya fokus kepada guru dan peserta didik yang menggunakan multimedia interaktif berbasis komputer. (3) Instrumen dokumen, yang digunakan sebagai penyempurnaan data yang diperoleh melalui instrumen wawancara, observasi, dan instrumen dokumen. Instrumen dokumen dalam penelitian ini berupa tulisan, gambar atau foto-foto, dan dokumen pendukung lain dari objek yang diteliti.

Analisis data dalam kualitatif dilakukan sebelum penelitian, selama penelitian dan setelah penelitian selesai. Teknik Analisis data yang dilakukan dalam penelitian ini adalah menggunakan model Miles dan Huberman yang dikenal dengan istilah Analysis Interactive. Analisis data pada model ini dilakukan ketika pengumpulan data berlangsung dan setelah pengumpulan datanya selesai, dalam periode 
tertentu. Jadi peneliti melakukan analisis mulai dari saat wawancara.

Data dianalisis dengan menggunakan model Analysis Interactive dengan beberapa tahapan yaitu pengumpulan data, reduksi data, penyajian data, dan penarikan kesimpulan atau verifikasi data.

Berikut ini gambar model Analysis Interactive:

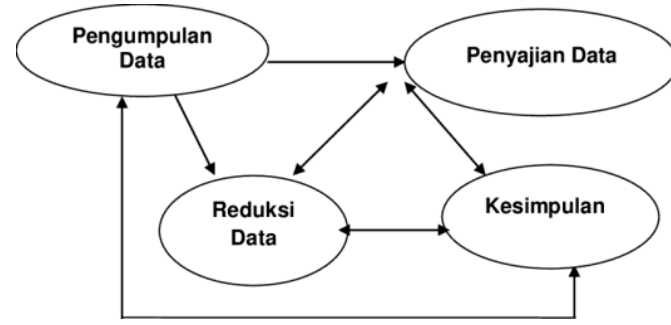

\section{Gambar 1. Desain Model Analysis Interactive}

Berdasarkan Gambar 1, analisis data dalam penelitian ini dilakukan melalui tahapantahapan. (1) Pada pengumpulan data, semua temuan yang terjadi melalui observasi dan wawancara dicatat. Hal ini dilakukan untuk mengetahui analisis kondisi peserta didik dalam menggunakan multimedia pembelajaran interaktif. (2) Setelah data terkumpul, kemudian ditelaah kembali catatan hasil pengamatan lalu memisahkan data yang dianggap penting dan tidak penting. Langkah ini diulang kembali untuk memeriksa kemungkinan-kemungkinan kekeliruan dalam klasifikasi. (3) Menyajikan deskripsi data yang telah diklasifikasikan dengan memperhatikan fokus dan tujuan penelitian. (4) Membuat analisis data akhir dalam bentuk laporan hasil penelitian. Data yang telah diperoleh dalam penelitian harus terlebih dahulu diverifikasi untuk mengetahui keabsahan dan kebenaran data tersebut.

\section{HASIL DAN PEMBAHASAN}

Hasil penelitian yang peneliti dapatkan terkait analisis penggunaan media pembelajaran interaktif yang digunakan guru untuk menstimulus motivasi peserta didik. Hal ini sesuai dengan pernyataan Arsyad (2015) yang menyebutkan bahwasanya penggunaan media pembelajaran interaktif dalam proses belajar mengajar dapat membangkitkan minat atau keinginan peserta didik dalam belajar.

Wawancara dilakukan dengan secara langsung kepada peserta didik dan guru yang telah melaksanakan kegiatan belajar mengajar dengan menggunakan multimedia interaktif. Responden untuk wawancara peserta didik dilakukan dengan memilih secara acak sebanyak 4 orang peserta didik untuk memberikan pendapatnya melalui wawancara. Proses wawancara peserta didik maupun guru dilaksanakan dengan memberikan pertanyaan sesuai dengan kisi-kisi yang telah disiapkan sebelumnya.

Berikut ini skrip wawancara kepada guru mata pelajaran matematika:

Pertanyaan 1 : "Apakah ibu pernah menggunakan media pembelajaran multimedia interaktif dalam mengajar matematika?"

Tanggapan : "Tidak pernah, karena jarang sekali ditemukan media pembelajaran interaktif di internet maupun di perpustakaan. Kalau harus buat sendiri tidak belum mahir."

Pertanyaan 2 : "Bagaimana dengan kehadiran multimedia interaktif yang dibuat dengan Lectora Inspire yang sedang dikembangkan?"

Tanggapan : "Terbantu, karena dengan saat latihan siswa jadi sibuk untuk belajar mandiri dan penasaran dengan isi aplikasi. Selain itu, dengan adanya video dalam multimedia interaktif ini, siswa jadi bisa mengulang materi."

Pertanyaan 3 : "Apakah penggunaan multimedia interaktif yang dibuat dengan Lectora Inspire ini dapat menambah motivasi peserta didik?"

Tanggapan : "Ya, motivasi siswa meningkat karena dengan satu siswa satu media, semua siswa aktif dan antusias mengikuti pembelajaran matematika. Pembelajaran matematika itu direkomendasikan untuk menggunakan media pembelajaran interaktif untuk menumbuhkan motivasi peserta didik."

Berikut ini skrip wawancara kepada Peserta Didik:

Pertanyaan 1 : “Apakah Anda pernah belajar matematika dengan menggunakan multimedia interaktif?"

Tanggapan Peserta Didik sebagai berikut: Siswa 1 : "Tidak pernah"

Siswa 2 : "Tidak pernah" 
Siswa 3 : "Tidak pernah"

Siswa 4 : "Tidak pernah"

Pertanyaan 2 : Bagaimana kesan Anda tentang media yang digunakan?

Tanggapan peserta didik sebagai berikut:

Siswa 1 : "Senang dan tertantang menggunakan media interaktif ini."

Siswa 2 : "Senang dengan media pembelajaran ini."

Siswa 3 : "Media ini mudah digunakan, memuat konsep-konsep dan pemahaman matematika."

Siswa 4 : "Saya bisa mengulang atau memutar ulang materi baik yang bentuk tulisan atau video."

Hasil dari wawancara yang dilakukan kepada guru tersebut dan hasil dokumentasi menyatakan bahwa guru tidak pernah menggunakan multimedia pembelajaran interaktif pada pelajaran matematika. Hal ini karena tidak ada source media pembelajaran yang ada di internet yang gratis dan belum bisa membuat sendiri. Penggunaan media pembelajaran ini juga bermanfaat karena dengan adanya media pembelajaran interaktif, guru merasa terbantu sehingga bisa lebih optimal dalam membimbing peserta didik satu per satu.

Mengenai pemanfaatan media pembelajaran multimedia interaktif terhadap motivasi belajar pada peserta didik ini, guru mata pelajaran juga berpendapat bahwa pembelajaran matematika itu direkomendasikan untuk menggunakan media pembelajaran interaktif untuk menumbuhkan motivasi peserta didik. Karena, dengan adanya penggunaan media multimedia interaktif bisa mempermudah dan bisa meningkatkan potensi belajar peserta didik. Penggunaannya juga perlu dikembangkan mengingat semakin pesatnya kemajuan teknologi saat ini. Jadi, dengan adanya penggunaan media pembelajaran multimedia interaktif kaitannya dengan peningkatan motivasi belajar pada peserta didik adalah peserta didik lebih fokus dan ini bisa menambah semangat belajar. Karena, dengan adanya penggunaan media multimedia interaktif bisa mempermudah dan bisa meningkatkan potensi belajar peserta didik. Penggunaan media pembelajaran interaktif perlu dikembangkan mengingat semakin pesatnya kemajuan teknologi saat ini.

Memanfaatkan komputer bagi pembelajaran merupakan salah satu kegiatan yang menjadi pendukung dalam menampilkan media pembelajaran interaktif yang dihasilkan oleh Lectora ini. Namun ada kendala yang dialami guru yaitu guru belum mahir dalam menggunakan komputer. Komputer hanya dapat diterapkan pada kelompok kecil dan tidak dapat diproyeksikan pada kelompok besar karena kepemilikan komputer di sekolah dengan peserta didik hanya 1 : 7 . Jadi penggunaan komputer tidak intens setiap pertemuan karena penggunaan laboratorium yang dilakukan secara bergilir. Kendala lain guru yang memanfaatkan media pembelajaran ini dengan memerlukan bantuan teknisi atau teman sejawat yang lebih ahli untuk membantu pemasangan media ini ke komputerkomputer yang ada.

Dari hasil wawancara yang telah dilakukan dengan 4 orang peserta didik menyatakan bahwa mereka belum pernah menggunakan media pembelajaran interaktif pada mata pelajaran matematika. Kesan dalam penggunaan media pembelajaran interaktif ini adalah mereka lebih senang dan tertantang menggunakan media interaktif ini. Tidak merasa bosan ketika berada di depan komputer. Peserta didik merasa senang karena media pembelajaran interaktif ini mudah digunakan, Memuat konsepkonsep dan pemahaman matematika, bisa mengulang-ngulang materi, baik materi tertulis maupun video.

Media pembelajaran ini disusun oleh Lectora Inspire. Media ini menyajikan materi dengan lengkap juga menarik karena adanya kombinasi materi berbentuk video, adanya audio/backsound dan animasi-animasi serta gambar latar belakang yang nyaman, contohcontoh soal pada media, evaluasi hingga warna yang digunakan tidak membuat peserta didik kesulitan dalam melihat media dari berbagai sisi dan penggunaan media yang mudah untuk dioperasikan. Dengan media pembelajaran interaktif ini, peserta didik tentu tertarik sehingga motivasi muncul untuk belajar matematika. Berikut Gambar 2 dan Gambar 3 adalah tampilan media yang digunakan.

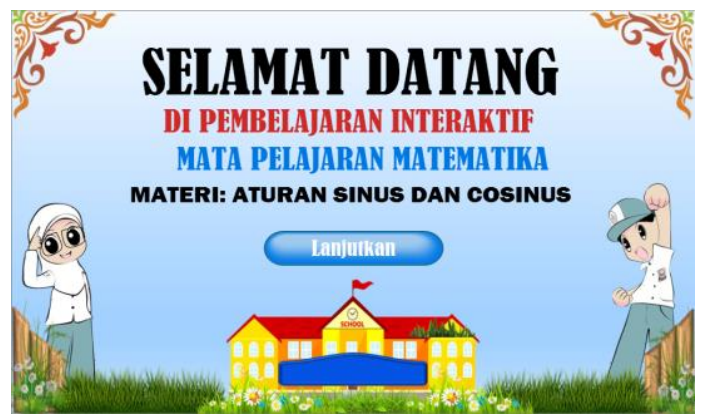




\section{Gambar 2. Halaman Sambutan Media Interaktif}

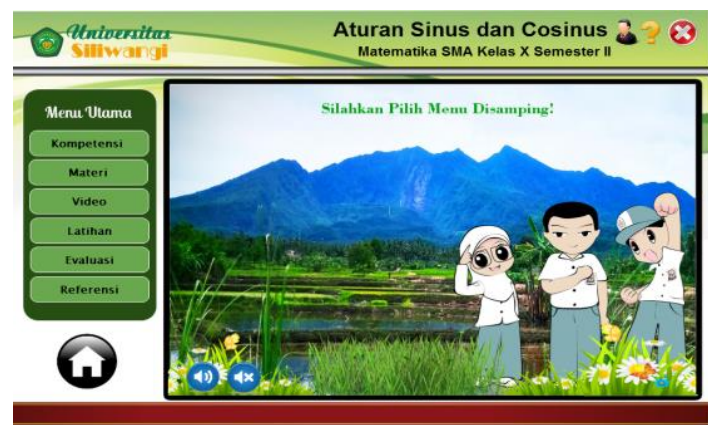

Gambar 3. Halaman Dashboard Media Pembelajaran Interaktif

Namun, ada beberapa kendala menurut peserta didik sudut dalam media pembelajaran ini diantaranya adalah penggunaan terlalu lama menyebabkan mata lelah dan mengantuk. Masih ada materi yang sulit dicerna, sehingga perlu penjelasan tambahan dari guru, terutama siswa yang sulit membangun konsep sendiri. Latar belakang kemampuan peserta didik yang berbeda juga menjadi kendala dalam penggunaan media berbasis teknologi karna tidak semua peserta didik memiliki kemampuan yang sama dan sebaiknya media efektif digunakan apabila tidak tergantung pada kemampuan anak.

Pada saat proses kegiatan penelitian ini, observasi yang dilakukan selama proses pembelajaran berlangsung menunjukkan hasil yang baik, ketika proses pembelajaran peserta didik begitu semangat, dan antusias ketika mengikuti pembelajaran karena adanya dukungan penggunaan media multimedia interaktif yang bertujuan menciptakan satu kondisi pembelajaran yang lebih terarah serta media yang digunakan relevan dengan materi yang sedang di pelajari. Tidak ada peserta didik yang pasif dalam kegiatan pembelajaran, semuanya aktif walau ada sebagian dari mereka yang masih ragu untuk menggerakkan pointer karena jarang mengoperasikan komputer, apa lagi di masa pandemi.

Ada semacam kebingungan pada peserta didik. Ini terjadi akibat ketidakbiasaan peserta didik menggunakan media pembelajaran interaktif berbasis teknologi. Disinilah hal yang tidak kalah penting untuk diperhatikan, dan tidak boleh ditinggalkan bahwa walaupun teknologi bisa menjadi sumber belajar, tetap tidak bisa menggantikan posisi guru. Karena ketika peserta didik bingung dan stuck, maka guru tampil aktif dalam memandu peserta didik terbut tanpa membiarkan yang lain tidak belajar karena ketersediaan penjelasan materi dalam media pembelajaran interaktif tersebut.

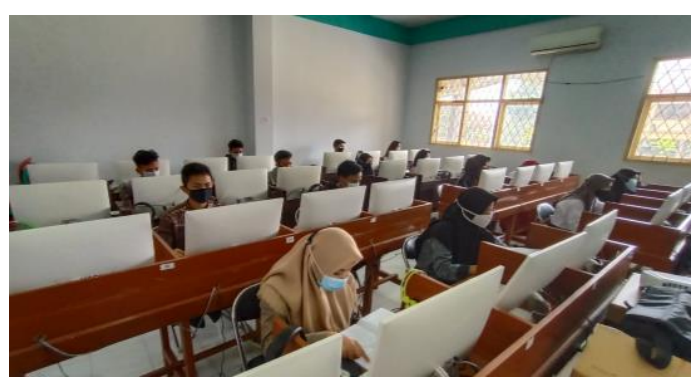

Gambar 4. Situasi Peserta Didik Proses

Belajar Mengajar dengan Media Pembelajaran Interaktif

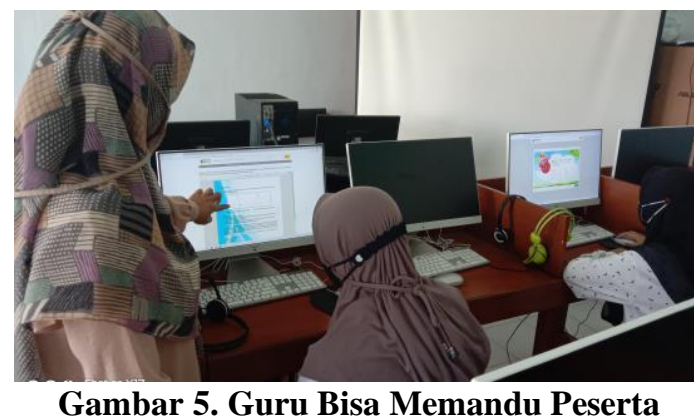
Didik dengan Intens

Pada hasil dokumentasi tercatat bahwa guru Matematika di MA Assa'adah jarang menggunakan teknologi untuk kegiatan proses kegiatan pembelajaran matematika apalagi melalui media pembelajaran multimedia interaktif dan perolehan nilai yang ada peningkatan. Peserta didik yang memperoleh nilai test.

Media yang digunakan dari segi penggunaannya sangat mudah dan membuat peserta didik menjadi lebih semangat dalam belajar karena tampilan dari media yang digunakan terdapat animasi-animasi yang membuat media tersebut menjadi lebih hidup dibandingkan dengan media-media lain yang belum memanfaatkan teknologi dalam penggunaannya. Pemilihan media yang tepat serta tampilan media yang baik akan membuat peserta didik aktif dan fokus mengikuti kegiatan pembelajaran, media pembelajaran multimedia interaktif bisa menarik motivasi belajar peserta didik hal ini terlihat dari timbulnya rasa ingin tahu dari peserta didik yang tinggi. Media pembelajaran multimedia interaktif sebagai salah satu media yang relevan dengan kemajuan teknologi saat ini sangat cocok untuk digunakan 
di sekolah. Media multimedia yang digunakan sudah sesuai dengan karakter peserta didik dan mampu membuat peserta didik termotivasi dalam proses pembelajaran serta mampu untuk mewujudkan terciptanya mutu pendidikan yang baik dan unggul.

Hal ini sejalan dengan penelitian yang dilakukan oleh Shalikhah (2017) yang menyatakan bahwa materi pelajaran dalam media pembelajaran dapat dimodifikasi menjadi lebih menarik dan mudah dipahami dengan tujuan agar suasana belajar yang asalnya menegangkan menjadi menyenangkan. Dengan menggunakan media pembelajaran interaktif, maka dapat membantu guru menciptakan pola penyajian yang interaktif. maka, guru perlu mengombinasikan berbagai jenis media dalam satu pembelajaran yaitu menggabungkan media berbasis visual, media berbasis audio, dan media berbasis kinestesis agar pesan bisa diserap oleh semua siswa dengan latar belakang berbeda.

Penelitian lain yang dilakukan Wahyuni, E. S., \& Yokhebed, Y. (2019), Sebaiknya guru menggunakan media pembelajaran dalam mengajar. Hal ini untuk memperjelas materi yang disampaikan. Manfaat media pembelajaran secara umum dalam proses pembelajaran adalah untuk memperlancar interaksi antara guru dengan siswa sehingga pembelajaran menjadi lebih efektif dan efisien. Penyampaian materi pelajaran dapat diseragamkan dan proses pembelajaran menjadi lebih jelas dan menarik, lebih interaktif, serta efisiensi dalam waktu dan tenaga, yang tentunya meningkatkan kualitas hasil belajar siswa. Media pembelajaran dapat menumbuhkan sikap positif siswa terhadap materi dan proses belajar, mengubah peran guru ke arah yang lebih positif dan produktif.

\section{SIMPULAN}

Berdasarkan pembahasan dari hasil analisis penggunaan media pembelajaran multimedia interaktif berbasis komputer terhadap motivasi belajar peserta didik di MA Assa'adah menggunakan teknik observasi, wawancara, dan dokumentasi, menunjukkan bahwa dengan adanya penggunaan media pembelajaran multimedia interaktif, peserta didik lebih fokus dan menambah semangat belajar. Media pembelajaran ini menyajikan materi dengan lengkap juga menarik karena adanya kombinasi materi berbentuk video, adanya audio/backsound dan animasi-animasi serta gambar latar belakang yang nyaman, contoh-contoh soal pada media, warna yang digunakan tidak membuat peserta didik kesulitan dalam melihat media dari berbagai sisi dan penggunaan media yang mudah untuk dioperasikan. Saat kegiatan pembelajaran dengan memanfaatkan penggunaan media pembelajaran multimedia interaktif peserta didik menjadi aktif dan semangat belajarnya terlihat tinggi, dari kegiatan pembelajaran hal ini terlihat yang bisa menjadikan peserta didik lebih antusias ketika mengikuti kegiatan pembelajaran matematika. Faktor utama penghambat kegiatan proses penyampaian materi pembelajaran yang dilakukan guru ketika pembelajaran bisa terpecahkan dengan adanya penggunaan media multimedia interaktif sebagai sarana belajar peserta didik di Madrasah Aliyah. Media multimedia interaktif yang digunakan di MA Assa'adah ini sudah sesuai dan tepat dengan karakter peserta didik.

\section{DAFTAR PUSTAKA}

A.M, Sardiman. 2012. Interaksi dan Motivasi Belajar Mengajar. Jakarta: Raja. Grafindo Persada.

Arsyad, A. 2015. Media pembelajaran. Jakarta: PT Rajagrafindo Persada. Hamalik,

Irwandani, I., Latifah, S., Asyhari, A., Muzannur, M., \& Widayanti, W. 2017. Modul Digital Interaktif Berbasis Articulate Studio'13: Pengembangan pada Materi Gerak Melingkar Kelas X. Jurnal Ilmiah Pendidikan Fisika Al-Biruni, 6(2), 221.

Karsidi, Dkk. 2018. Media pembelajaran inovatif dan pengembangannya. Bandung: Rosdakarya.

Kustandi, C. and Darmawan, D., 2020. Pengembangan Media Pembelajaran: Konsep \& Aplikasi Pengembangan Media Pembelajaran bagi Pendidik di Sekolah dan Masyrakat. Prenada Media.

Mulongo, G. 2013. Effect of Active Learning Teacher Methodology on Learner Participation Institue of Education. Journal of Education and Practice, 4 (4):157168.

Purworini, D. 2014. Model Informasi Publik di Era Media Sosial : Kajian Grounded Teori Di Pemda Sukoharjo. KomuniTi: Jurnal Komunikasi Dan Teknologi Informasi, 6(1), 3-14.

Putri, A. N., \& Suparman. 2019. Analisis Kebutuhan E-LKPD Untuk Menstimulus Kemampuan Komunikasi Matematis Siswa. The 1st Steeem 2019, 1(1), 193197. 
Setiawan, A., Putria, A., \& Suryani, N. 2020. Media pembelajaran inovatif dan pengembangannya. Bandung: Rosdakarya

Shalikhah, N. D. 2017. Media Pembelajaran Interaktif Lectora Inspire sebagai Inovasi Pembelajaran. Warta LPM, 20(1), 9-16.

Sugiyono. 2008. Metode penelitian pendidikan:(pendekatan kuantitatif, kualitatif dan $R \& D)$. Alfabeta.

Wahyuni, E. S., \& Yokhebed, Y. 2019. Deskripsi Media Pembelajaran Yang Digunakan Guru Biologi Sma Negeri Di Kota Pontianak. Jurnal Pendidikan Informatika Dan Sains, 8(1), 32.

Wijayanti, I. K., \& Retnawati, H. 2019. Analisis profil kesiapan siswa SMA dalam menghadapi ujian nasional matematika di Kabupaten Temanggung. Jurnal Pendidikan Matematika dan Sains, IV(1), 1-3.

Wulandari, Bekti. 2017. Pembuatan Media Pembelajaran Dengan Lectora Inspire. 5. http://staffnew.uny.ac.id/upload/1988122 42014042002/pengabdian/Modul Lectora 2017.pdf 